\title{
Economic and Social Turmoil in Venezuela Caused by Autocracy and Misgovernance
}

\author{
Subhendu Bhattacharya ${ }^{1 *}$, Y. Nisha ${ }^{2}$ \\ ${ }^{1}$ Assistant Professor, Department of Management, Amity Global Business School, Mumbai, India \\ ${ }^{2}$ Associate Professor, Amity Global Business School, Mumbai, Mumbai, India \\ *Corresponding author: subh.econ@gmail.com
}

\begin{abstract}
Venezuela was once a thriving economy but it experienced one of the worst political crisis and economic catastrophe in modern times. The failure of leadership and erroneous policy measures were instrumental in this disaster. After Hugo Chavez, his successor Nicolás Maduro from socialist PSUV party took over in 2013. His extension through the general election in May 2018 remained shrouded under controversy. There was massive corruption, social repression, deceleration of productivity, economic indecision, higher dependence on oil, rampant human rights violation, and shutdown of businesses noticed during his regime. Venezuela is an oil rich country with the leading verified oil reserves in the world. Its economy is highly dependent on oil exports but oil production has plummeted tremendously. The nation failed to diversify in other lines of production even as oil prices started to fall since 2014 and the economy suffered beyond measure. As per IMF estimate, Venezuela's economy has shrunk by more than one-third between 2013 and 2017 approximately. Its currency value reduced to rubble, inflation skyrocketed, GDP growth rate went into tailspin and debt defaulted. There is unprecedented humanitarian crisis in Venezuela in recent times. Rise in violence and crime, hunger, malnutrition and poverty led millions of people to flee the country. As per the United Nations' record, about 4.8 million Venezuelans left the nation since the crisis erupted in 2014. US imposed sanction on Venezuela in 2015 which further got intensified in 2017. There is now international pressure on Nicolás Maduro to step down and to allow his opponent Juan Guaidó to run the country. In the times of the Corona virus outbreak, this crisis has aggravated for the economically impaired nation.
\end{abstract}

Keywords: Corrupt practices, Distraught population, Economic slump, Reduced oil production, Scarcity of bare necessities, Social hardship.

\section{Case Study}

Venezuela had a glorious past but is currently reeling under monumental economic and humanitarian crisis. Its economy had remained highly dependent on oil and petroleum products. The chief industrial activities centered on oil production, refining of crude oil and export of oil for earning of foreign exchange. The oil revenue constituted about 99 percent of export earnings. However, since the economic recession of 2008, Venezuela started facing uncertainties. The situation improved a little during 2010-2012 but plunged into deeper crisis after that. In 2013 there was transfer of power as popular leader Hugo Chavez passed away and his close associate Nicholas Maduro took over. There was severe policy failure under the new leadership and economic hardships aggravated. Production of oil started to fall sharply. As per data of Center for Strategic and International Studies report of June 2018, Venezuela's crude oil production plummeted to a 50 years low. Since Maduro's ascendance to power, inflation remained high and gradually spiraled out of control. Currency exchange rate for Venezuelan bolivar went down drastically and never recovered. GDP growth rate receded and declined below -15 percent. As per estimate of United Nations Economic Commission for Latin America and the Caribbean, 90 percent of Venezuelans are poverty-stricken. The people are frustrated with the high level of corruption and autocratic regime. The acute shortages of food and basic needs has led to millions of people fleeing to neighboring Latin American countries, Spain and US. Political clash with US also led to imposition of rigorous sanctions on Venezuela and trade was impeded. US also froze $\$ 5.5$ billion of Venezuelan funds in international accounts at numerous financial institutions which was a mortal blow to the moribund economy. Thereafter the outbreak of COVID 19 further impacted the economy adversely. Dwindling healthcare facility and lack of medical supplies created massive inconvenience to fight against the deadly virus in 2020. It remained as one of the most ill-prepared nation to face global pandemic. Lives of people were threatened in the absence of proper medical facilities and social distancing was violated rampantly as people struggled hard to get basic supplies. As per a study by the World Food Program one in three people in Venezuela didn't get food to eat. United Nation Human Right Council reporters mentioned about severe failure of human rights in the light of authoritarian crackdown on civil right campaigners, protesters and correspondents. Social dissent and grudges piled up against existing regime. Opposition leader Juan Guaido garnered support at home and from external governments of Europe, North America and Asia.

\section{Historical Background}

It is necessary to have a look at Venezuela's historic journey to understand the gradual evolution of glory which has now got tarnished. Severe decadence of economic status has led to its 
fall from the grace since 2018-19. Venezuela was one of the leading Latin American countries officially known as Bolivarian Republic of Venezuela. This former Spanish colony at the foothill of Andes mountain range had a checkered historic past ranging from economic stability and sustained progress during most of 1950 to 1973 and crestfallen moments in 1980s due to sharp reduction in oil price. Venezuela took pride in its transformation from comparatively pitiable agrarian economy dependent on cash crops such as coffee and cacao to expeditious urbanized society. The real turnaround for the country happened due to discovery of oil reserve in the early 20th century. Since then Venezuela became chief exporter of oil in the world and is regarded as founder member of OPEC. It was characterized as a market-based mixed economy dependent on petroleum sector which contributed about one-third of its GDP and accounted for $90 \%$ of exports. This resulted in magnum revenue earning for govt. exchequer. The status of possessing world's largest oil reserves and frontrunner in oil export led to economic prosperity. The significant gain was felt in 1970s when OPEC hiked oil price by 400 percent in 1973. Windfall profit and increase in oil income helped the country to wield influence in Latin America. It capitalized favorable trade deal with neighboring nations for oil and natural gas. The fortune however didn't last long as the economy plunged into debt crisis in 1982 and suffered oil price collapse in 1986. Current account deficit led to foreign exchange crisis and depletion of foreign exchange reserve. It triggered economic destitution. To address balance of payment crisis and set right economic anomalies Venezuela signed treaty with IMF and World Bank in 1989. Nevertheless, economic distress kept on haunting all through 1990s. The reasons ranged from unstable oil price, political unsteadiness, banking turmoil in 1994, mismanagement and indebtedness of the Central Bank. The government consequently divested various financial institutions in 1990s and concluded with more than half of Venezuela's banks being controlled by foreign investors. Nagging economic concerns brought incumbent government back to wall. In a desperate bid, government came up with Agenda of Venezuela plan in 1996 in which it lost some control over financial system and privatized numerous industries. This measure didn't ensure much relief. Revenue earning based on fluctuating oil prices were not enough to support rising government expenditure. Rising inflation remained a sore since the beginning of 21 st century. But as oil price started to escalate since 2003, economy rebounded enough to repay its loans of IMF and World Bank and subsequently detached from them. To address the persisting inflation and sort out financial complications, the nation introduced new currency bolívarfuerte in 2008. Sharp spike in oil price acted as a cushion when level of poverty and inflation soared since 2010.

\section{The Regime of Hugo Chavez}

There were perceptible imbalances in regional growth and socio-economic status. Thriving oil industry and improvement in social infrastructure led to massive internal migration and influx of immigrants from neighboring nations such as Columbia, Peru, Chile and Brazil. The predecessor of present president had a massive contribution in economic transformation and social upliftment. Oil rich economy progressed enormously under able leadership of revolutionary leader Hugo Chavez who was in power since 1999 and continued till he breathed his last in 2013. Riding on stratospheric oil revenue in 2000s, Chavez unleashed nationalization drive for key industries and initiation of social welfare program. It improved accessibility to food, housing, healthcare and education for the common masses to a great extent. The initial phase of Chavez tenure was marked by remarkable profit from oil export and improvement in quality of life due to economic welfare measures. Although, nothing much was done on deep-seated structural inequalities, President Hugo gained massive public support through socialist sentiments and anti-US foreign policy. Chavez administration had always maintained anti-imperialist stance, opposed globalization process and maintained nationalistic drive wholeheartedly. His administrative standpoint was to dismantle economic disparity, culmination of private property and implementation of land reforms to facilitate the poor. Free press during last two authoritarian regimes had been highly regulated and restricted. Abolishment of private property earned enough criticism from affluent class and opposition. The continuous opposition with US had been evident for couple of decades. In order to control US influence in Venezuela and other Latin American nations, Hugo administration went ahead with generous loan package for neighbouring nations. Venezuela had always remained pro-communist and anti-capitalist nation and it reflected in its close connection with Russia for arms deal, oil and gas cooperation. For satellite telecommunications facility Venezuela took Chinese assistance. Much touted Bolivarian Missions in sync with Millennium Development Goals was instrumental for social development in 2000s. It worked well initially with other contemporary social policies for improvement in areas like health, education, and alleviation of impoverishment but it drained government exchequer. Unlike other OPEC members, Hugo administration didn't care about saving funds for economic uncertainties and went overboard on spending in public work. The fire-fighting measure was undertaken to stem economic fallout by imposition of currency control as capital flight brought down currency value and made room for parallel dollar market.

The economic problems in Venezuela started to creep in since the last quarter of 2009 when economy contracted by $5.8 \%$ and president Chavez had to devalue Venezuelan currency Bolivar to stimulate revenue earning from oil export. In two successive years GDP growth rate declined and unemployment rate and govt. debt rose to a significant high. From 2011 the situation recovered marginally due to stability in oil production and consistency in high crude oil price. Instead of addressing root cause of inflationary trend, people friendly 
government extended price control on basic goods in April 2012 and threatened to expropriate companies on noncompliance issue. Adversity started to creep in since 2013 and economy never revived from steep downfall.

\section{Evolution of Current Crisis}

After 14 years of unpredictable and volatile regime, Hugo Chavez died of Cancer in 2013 and left behind his legacy for his right-hand compatriot Nicolás Maduro. He was an active member of socialist PSUV party which governed Venezuela for two decades and was instrumental in gaining control over prominent institution such as most of judiciary, electoral council and Supreme Court. Chavez's regime though was mired in corruption and ineffective policy measure but his mission to improve condition of poor with oil wealth had helped to garner support of common people. Irrespective of myopic economic and external affair outlook, his strategy to harness nation's oil treasure to fund welfare measure worked well to address inequality and poverty on the home front. After the untimely demise of the popular leader, Vice President Nicolás Maduro took over presidency and won election subsequently on a narrow margin. He was not as fortunate as his predecessor. Since his ascendency to power, the economy displayed downturn tendency. Inflation in 2013 went beyond 50 percent. National assembly authorised emergency power to him in November 2013. As economic crisis deepened, he chose to curtail welfare spending massively. There was some symmetry between decline in oil price in world market and reduction in oil production reflected in following diagrams.

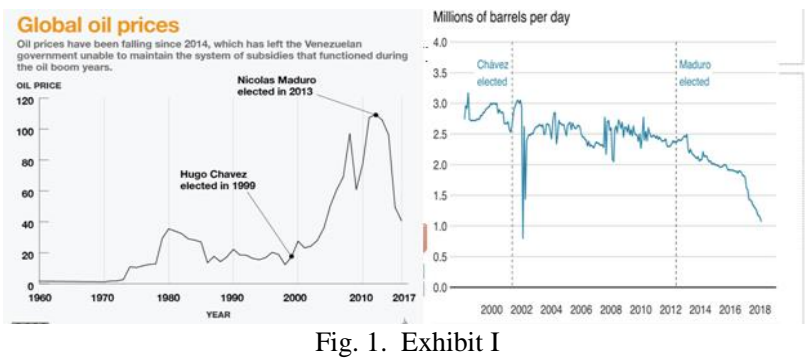

Source: OPEC Annual Report 2018,

https://www.opec.org/opec_web/static_files_project/media/downloads/publica tions/AR\%202018, April 2018

Like several petro-states, Venezuela fought hard to diversify its economy, left at the mercy of boom-bust cycles. When oil became costly, government exchequer overflowed. When it became inexpensive, coffers depleted. The above two adjacent diagrams portray how the fortune of oil-based economy evaporated with oil price collapse in world market. Oil business is regarded as capital-intensive. To ensure sustainable production, Venezuela required reinvesting a sufficient portion of boon from prosperous years into its state-owned oil company, Petróleos de Venezuela, or PDVSA. But it never happened. Venezuela used to produce approximately 3.5 million barrels of oil per day in 1999. Production plummeted deeply to less than one-third of that in 2018. The economy thus got stranded in crippling recession in absence of oil revenue. The US sanctions in 2017 too caused an insult to injury.

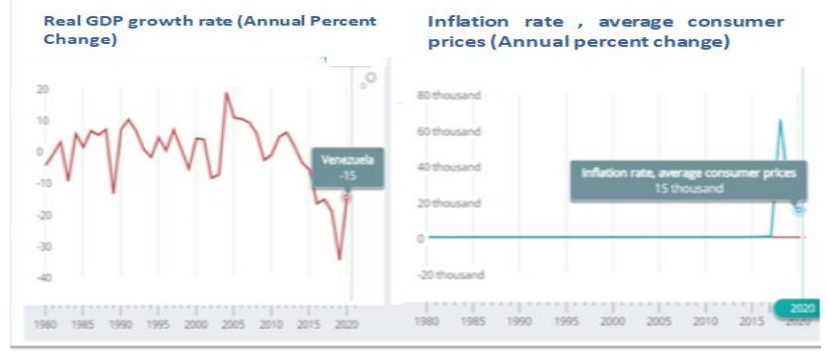

Fig. 1. Exhibit II

Source: IMF DataMapper, Venezuela Country data,

https://www.imf.org/en/Countries/VEN\#countrydata, April 2020

In the above two adjacent diagrams, we find decline of real GDP growth rate and inflation rate as refereed in the form of annual percentage change for average consumer prices. Both are time series data and showed the percentage change since 1980. Real GDP growth rate reached its peak in 2005 during heydays of charismatic leader Hugo Chavez. But good time didn't last long. After 2008 recession, economy improved marginally but fell miserably after that to reach -15 percent in recent times. Inflation was in the range of 5 to 40 percent during 2000 to 2013 but it went through the roof and hyperinflation reached 15 thousand percent level in current period. Monetary policy by the central bank of Venezuela failed to contain unusual surge in inflation and restrict the massive depreciation of currency value. Suffering in normal lives remained indescribable as currency lost purchasing power completely and scramble for food and basic necessities led to burglary and riot in places. There was lack of coordination between fiscal and monetary policy. Monetary policy remained fragile to tackle fiscal imprudence and indiscipline.

\section{The Real Fact of Challenging Time}

President Maduro's leadership was under question mark since he took charge in 2013. It was evident that he inherited an embattled economy plagued by multiple challenges. Like his predecessor, he tried to strengthen social, political, and economic ties in Latin America and sidetracked American authority in the South American landscape. His friendship with tainted leaders like Libya's Muammar al-Qaddafi, Zimbabwe's Robert Mugabe, and Iran's Mahmoud Ahmadinejad didn't improve his image at all. Nicolas Maduro lacked economic prudence to bring economy back on track. He was re-elected as president for a second six-year term in May 2018, in a poll blemished by an opposition boycott and suspicion of malpractice in election process. Opposition chief Juan Guaidó proclaimed himself as provisional president in early 2019 and pleaded to military to expel President Maduro. He garnered support from the European Union, United States, and most Latin American countries. Pitiable president Maduro left reliant 
on the army and drew international support from Russia and China. Economic downfall and social misery cracked open his already crumbling citadel. Also the outbreak of COVID 19 proved to be fatal for ill-fated nation whose medical facility is in dire straits. Coup against Maduro had been foiled in May 2020 but threat remained perceptible for incumbent authority in the face of economic doldrums. The problems are multipronged. GDP dipped into negative double digit level. Oil production shrunk manifold to be about one-fourth of 2008 level. Venezuelan oil price per barrel reached below 10 dollar in world market in April 2020. Currency bolivar stayed in free fall and inflation reached sky high. Debt burden mounted high and FDI cut a dismal picture. Per capita income spiralled down and about 90 percent of population kept reeling under poverty. Provision for food, basic necessities dried up and demonstrations faced severe clamp down from ruling authority. The rising graph of hunger, malnutrition, deprivation, violation of human right, spread of communicable disease and lack of medical facility led millions of people to flee the country since 2014. Unless there is political goodwill and structural reform of economy, peace and stability would remain a far cry in this fateful nation. Assembly election victory of Nicolás Maduro in December 2020 received only 31 percent turnout of voters and was challenged by opposition and US as well as numerous EU nations. It remains unclear whether the new term of autocratic regime will be able to cause a turnaround for the nation wrecked by social tragedy and economic meltdown.

\section{Conclusion}

This paper presented an overview on economic and social turmoil in Venezuela caused by autocracy and Misgovernance.

\section{References}

[1] A. Berwick, and S. Kinosian, "Venezuela wields a powerful 'hate' law to silence Maduro's remaining foes," Special Report- Reuters, December 14, 2020.

[2] Editorial, "Maduro's win: On Venezuela election," The Hindu, December 12,2020

[3] ET News, "Venezuelan oil price falls below $\$ 10$, lowest level in 20 years",

https://economictimes.indiatimes.com/markets/commodities/news/venez uelan-oil-price-falls-below-10-lowest-level-in-20years/articleshow/75371724.cms, April 25th, 2020

[4] Megan Specia, "Five Things You Need to Know to Understand Venezuela's Crisis," The New York Times, https://www.nytimes.com/2019/05/03/world/americas/venezuela-crisisfacts.html , May 3rd, 2019

[5] P. Sabga, "What brought Venezuela's economy to ruin?," AlJazeera News, https://www.aljazeera.com/news/2019/02/brought-venezuela-economyruin-190201152238535.html, February 1st 2019.

[6] P. J. Kiger, "How Venezuela Fell from the Richest Country in South America into Crisis," History website, May 9th, 2019 https://www.history.com/news/venezuela-chavez-maduro-crisis,

[7] T. Phillips, "Maduro tightens grip over Venezuela with win in boycotted congress vote," The Guardian, Rio de Janeiro, December 7, 2020.

[8] United Nation News, "Venezuelans 'teetering on the brink of survival' warn UN human rights experts," https://news.un.org/en/story/2020/05/1063372, May 6th 2020.

[9] Visual Journalism team- BBC News, "Venezuela: All you need to know about the crisis in nine charts," February 4th 2019. 